\title{
PERENCANAAN PEMBANGUNAN GUGUS PULAU SAPEKEN SECARA BERKELANJUTAN: PENILAIAN DAYA DUKUNG KAWASAN BAGI PENGEMBANGAN WISATA
}

\author{
Planning For Sustainable Development At Sapeken Archipelago: \\ Carrying Capacity Area Assessment For Tourism Development
}

\section{A. Romadhon 1, F. Yulianda 2, DG. Bengen ${ }^{2}$, L. Adrianto ${ }^{2}$}

Diterima : 22 Maret 2013 Disetujui: 28 Juni 2013

\begin{abstract}
Abstrak: Tantangan perencanaan di pulau kecil adalah untuk memastikan efisiensi penggunaan sumber daya lahan yang terbatas, menjamin pembangunan daerah dan penggunaan sumber daya seimbang. Berdasarkan daya dukung dan tujuan pulau kecil, perencanaan tata ruang wisata di kepulauan Sapeken yang terdiri dari beberapa pulau, dilakukan dengan menganalisis kesesuaian kepulauan Sapeken selama beberapa pariwisata. Selanjutnya, menghitung kapasitas dengan merujuk Yulianda, et.al (2010) untuk menilai seberapa banyak pariwisata dapat diakomodasi tanpa menyebabkan gangguan alam. Hasilnya menunjukkan kepulauan Sapeken memiliki wilayah yang cocok untuk wisata selam $(164,42$ ha), snorkeling (361,56 ha), memancing pariwisata (1.493,38 ha), pariwisata bakau (3.927,09 ha) Dan pantai pariwisata (39,77 ha). Kapasitas kepulauan Sapeken yaitu 4260 orang / hari untuk wisata selam, 3590 orang/hari untuk snorkeling, 14900 orang / hari untuk pariwisata perikanan; 321. 000 orang / hari untuk wisata mangrove, dan 199 orang / hari untuk wisata pantai.
\end{abstract}

\section{Kata kunci: Kepulauan Sapeken, Analisis Kesesuaian, Daya dukung, Wisata}

Abstrak : The challenge for planning in small island is to ensure efficient use of limited land resources, ensure balanced regional development and balanced use of resources. Based on carrying capacity and small island destination, spatial planning of tourism in Sapeken archipelago which contaian several small island, done by suitability analyze Sapeken archipelago for several tourism. Furthermore,carrying capacity calculated referring Yuliandaetal(2010) to assess how much tourism can commodate without causing disruption the nature. The result suggest Sapeken archipelago have suitable area for dive tourism (164.42 ha); snorkeling (361.56 ha); fishing tourism (1493.38 ha), mangrove tourism (3927.09 ha) dan beach tourism (39.77 ha). Carrying capacity for tourism activities,Sapeken archipelago can commodate 4260 person/day for dive tourism; 3590person/dayfor snorkelling; 14 900people/day for fishing tourism; 321. 000people/day formangrovetoursm; and 199 people/day for beach tourism.

Keywords : Sapeken archipelago, suitability analyze, carrying capacity, tourism

\footnotetext{
${ }^{1}$ Jurusan Ilmu Kelautan, Fakultas Pertanian, Universitas Trunojoyo Madura

Jl. Raya Telang Kamal - Bangkalan - Madura

${ }^{2}$ Departemen. Manajemen Sumberdaya Perairan, Fakultas Perikanan dan Ilmu Kelautan,IPB

Jl. Agatis Kampus IPB, Darmaga, Bogor - Jawa Barat 16680
}

Korespondensi : aromadhon46@gmail.com 


\section{Pendahuluan}

Gugus pulau-pulau kecil (archipelagos) diistilahkan sebagai kumpulan dari sejumlah pulau-pulau kecil atau perairan laut yang didalamnya tersebar pulau-pulau kecil (Bardolet dan Sheldon, 2008). Lebih lanjut kumpulan pulau-pulau kecil tersebut secara geografis saling berdekatan dimana ada keterkaitan erat dan memiliki ketergantungan atau interaksi antar ekosistem, kondisi ekonomi, sosial dan budaya baik secara individu maupun kelompok (DKP, 2000). Sebagai sebuah entitas di wilayah pesisir dalam pengembangannya sering dihadapkan pada kendala ukuran fisik (smallness) yang sering menjadi penghambat dalam mencapai skala ekonomi yang menguntungkan. Terkait dengan hal tersebut dalam perspektif pembangunan pulau-pulau kecil, opsi pembangunan yang paling tepat berupa aktivitas yang hanya sedikit dampak negatifnya (Bengen, 2007), salah satunya adalah kegiatan wisata.Pendapat tersebut menjadi intuisi meski ukuran kecil bisa menghambat ekonomi namun kinerja wisata telah menjadi penggerak penting untuk mengatasi kendala tesebut (Conlin dan Baum, 1995; Apostolopoulos dan Gayle, 2002).

Wisata sering dianggap kesempatan untuk mempromosikanpembangunan ekonomi dan social pada pulau-pulau kecil. Faktor-faktor biologis seperti flora dan fauna dan estetika lanskap telah muncul sebagai aset ekosistem paling berharga dan juga menjadi sumber daya wisata paling berharga (Pavlikakis dan Tsihrintzis, 2006).Pada kawasan pulaupulaukecil dankepulauan, ekosistem sebagai natural capital asset memiliki batas pemanfaatan (daya dukung). Untuk itu kegiatan wisata atau ekowisata yang akan diimplementasikanharusdapatberkontribusi terhadapkonservasi danpemanfaatansumber dayalaut dan daratsecara berkelanjutan (White dan Rosales, 2001). Pemanfaatan berkelanjutan dan batasan daya dukung ini menunjukkan perlunya penerapan konsep sustainable developmentdalam perencanaan wisata pada kawasan kepulauan dan pulaupulau kecil. Oleh karena itu, pengembangan destinasi ekowisata memerlukan perencanaan tata ruang untuk menghindari dampak perubahan pada lanskap, dan menjaga keamanan proses ekologi, budaya dan perseptif (Yu et al, 2001).

Perencanaan tata ruang dapat digunakan sebagai alat untuk melakukan sustainable development dengan mengkoordinasikan aspek sosial, pembangunan ekonomi ramah lingkungan dan sekaligus melindungi lingkungan alam dan budaya. Tantangan untuk perencanaan wisata adalah untuk memastikan pemanfaatan sumber daya yang efisien melalui penggunaan sumber daya yang seimbang, termasuk sumber daya alam dan sumber daya lanskap.

\section{Metode}

\section{Lokasi penelitian}

Penelitian dilakukan pada kawasan gugus Pulau Sapeken. Data yang dikumpulkan berupa statusekosistem laut (terumbu karang, mangrove, pantai, perikanan), kondisi oceanografi dan kondisi klimatologi

Pelaksanaan perencanaan kawasan (spatial plan) didasarkan atashasil penilaian kesesuaian kondisi lingkungan untuk kegiatan wisata. Kondisi lingkungan yang dimaksud meliputi sejumlah parameter terkait dengan peruntukan sejumlah jenis wisata. Adapun analisa yang digunakan sebagai berkut :

\section{Analisis Kesesuaian Kawasan}

Analisis kesesuaian kawasan yang akan dilakukan adalah kesesuaian kawasan untuk kegiatan wisata dengan kategori aktivitas sebagai berikut : 1) wisata pantai; 2) wisata mangrove; 3). wisata selam; 4) wisata snorkeling; dan 5) wisata pancing. Semua kategori 
wisata ini akan memanfaatkan ekosistem dan sumberdaya pesisir dan laut yang terkait sebagai objek.

Secara umum terdapat empat tahapan analisis yang akan dilakukan, yaitu 1) penyusunan peta kawasan;2) penyusunan matriks kesesuaian setiap kegiatan yang akan dilakukan (terbagi 3 kelas yaitu sesuai (S), sesuai bersyarat (SB) dan tidak sesuai (TS);3) pembobotan dan pengharkatan; dan 4) melakukan analisis spasial untuk mengetahui kesesuaian dari setiap kegiatan yang akan dilakukan.

Algoritma yang digunakan untuk penilaian nilai indeks kesesuaian masing-masing jenis wisata, sebagai berikut :

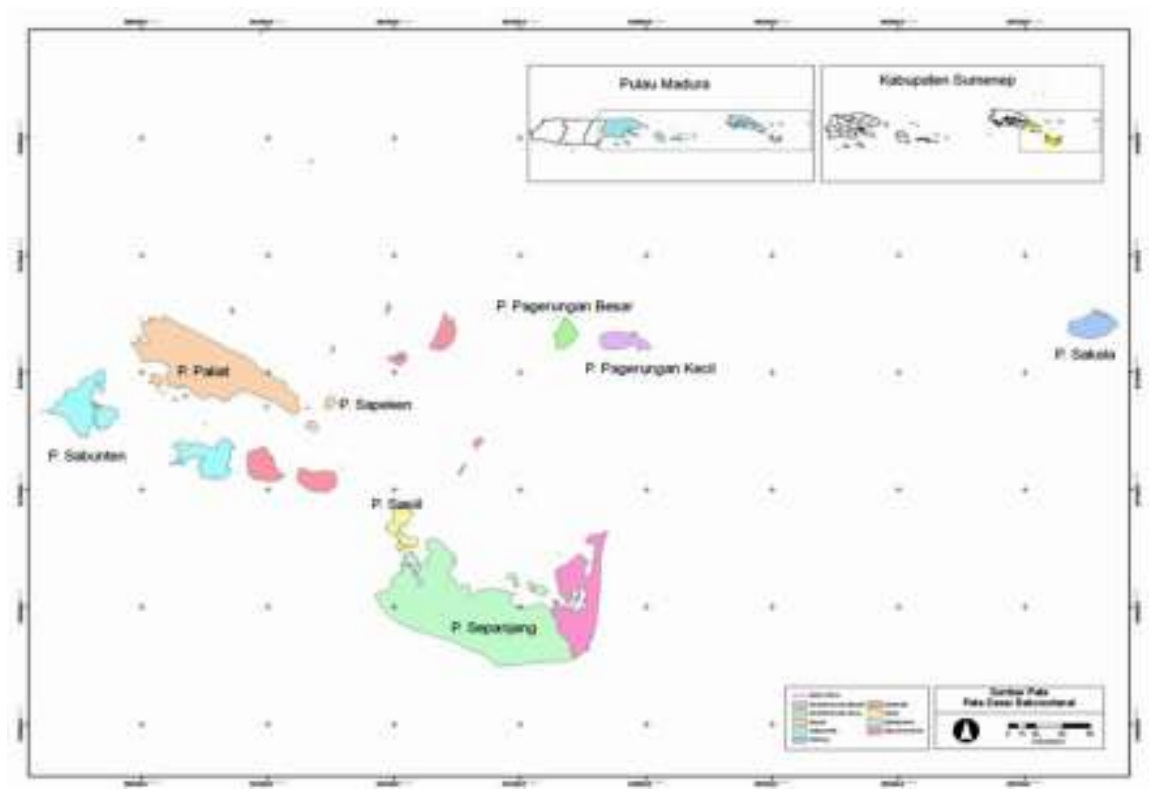

Wisata selam

Wisata snorkeling

Wisata pancing

Wisata mangrove

Wisata rekreasi
Gambar 1. Gugus Pulau Sapeken

: Jns Ikrng (0.19 x skor $)+$ Kec.Per $(0.19$ x skor $)+$ Ttpn krng (0.12 x skor $)+$ Jns lifrm (0.12 x skor $)+$ Suhu ( $0.12 \times$ skor $)+$ Sal $(0.12 \times$ skor $)+$ Ked krng (0.12 x skor) $+\operatorname{Kec}$ Ars (0.04 x skor)

Ttpn krng (0.24 x skor) + Jns lifrm (0.24 x skor) + Kcrh (0.14 x skor) + Jns Ikrng (0.14 x skor) + Kec Ars (0.14 x skor) + Ked krng (0.05 x skor) + Lbr krng (0.05 x skor)

Jns ikn (0.23 x skor) + Kec Ars (0.23 x skor) + Ting Gel (0.23 x skor) + Kcrh (0.14 $\mathrm{x}$ skor $)+$ Suhu (0.05 x skor) + Sal (0.05 x skor) + Ked air (0.05 x skor) + Jrk kwsn lain $(0.05 \mathrm{x}$ skor $)$

Ktbl Mgrv (0.28 x skor) + Krpt Mgrv (0.28 x skor) + Jns Mgrv (0.17 x skor) + Jns bio $(0.17 \mathrm{x}$ skor $)+$ Ting Pst $(0.05 \mathrm{x}$ skor $)+$ Jrk kwsn lain $(0.05 \mathrm{x}$ skor $)$

: $\quad$ Tip Pnt $(0.18 \times$ skor $)+$ Lbr Pnt $(0.18 \times$ skor $)+$ Ked air $(0.18 \times$ skor $)+$ Mtri air (0.11 x skor) + Kec Ars (0.11 x skor) + Kmrng Pnt (0.11 x skor) + Kcrh $(0.04 \mathrm{x}$ skor) + Pntpn Pnt (0.04 x skor) + Biota Bhy (0.04 x skor) + Ktrs air (0.04 x skor) 
Nilai indeks kesesuaian wisata dihitung mengacu pada Yulianda et al (2010) dengan menggunakan persamaan berikut :

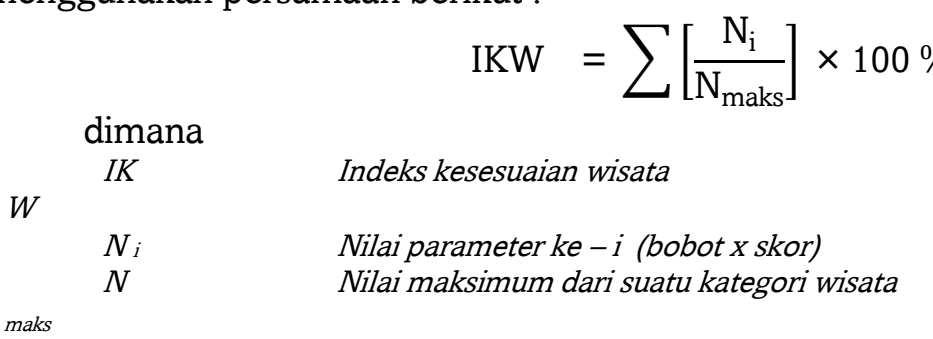

\section{Analisis Daya Dukung Kawasan}

Daya dukung kawasan untuk kegiatan wisata dihitung berdasarkan atas kemampuan ekosistem untuk menyediakan ruang pada waktu tertentu bagi bagi wisatawan secara fisik tanpa menimbulkan gangguan pada alam dan manusia Yulianda et al (2010). Hasil dari analisa kesesuaian untuk tiap jenis wisata yang akan dikembangkan berupa luasan bagi kelas kesesuaiansesuai (S) dan sesuai bersyarat (SB). Persamaan yang digunakan dalam menghitung daya dukung kawasan (DDK) dan daya dukung pemanfaatan (DDP) sebagai berikut :

$$
\mathrm{DDK}=\mathrm{K} \times\left[\frac{\mathrm{L}_{\mathrm{p}}}{\mathrm{L}_{\mathrm{t}}}\right] \times\left[\frac{\mathrm{W}_{\mathrm{t}}}{\mathrm{W}_{\mathrm{p}}}\right]
$$

dimana

$\mathrm{DD}$

Daya Dukung Kawasan

$\mathrm{K}$

$\mathrm{K} \quad$ Potensi ekologis pengunjung per satuan unit area

L $p \quad$ Luas area atau panjang area yang dimanfaatkan

$\mathrm{Lt} \quad$ Luas unit area untuk kategori tertentu

W t Waktu yang disediakan oleh kawasan untuk kegiatan wisata dalam satu hari

W Waktu yang dihabiskan oleh pengunjung untuk setiap kegiatan tertentu

$\mathrm{p}$

$$
\mathrm{DDP}=\mathrm{DDK} \times 0.1
$$

Tabel 1 Potensi ekologis pengunjung (K) dan luas area kegiatan (Lt)

\begin{tabular}{llllll}
\hline No & Jenis kegiatan & $\begin{array}{l}\sum \text { pengunjung } \\
\text { (orang) }\end{array}$ & Luas area (L t) & Keterangan \\
\hline 1 & Rekreasi pantai & 1 & 50 & $\mathrm{~m}$ & 1 orang tiap 50 m panjang pantai \\
2 & Wisata mangrove & 1 & 50 & $\mathrm{~m}$ & Dihitung panjang track tiap orang dalam $50 \mathrm{~m}$ \\
3 & Wisata lamun & 1 & 500 & $\mathrm{~m} 2$ & Tiap orang dalam 100 x 5 m \\
4 & Snorkeling & 1 & 500 & $\mathrm{~m} 2$ & Tiap orang dalam 100 x 5 m \\
5 & Selam & 2 & 2500 & $\mathrm{~m} 2$ & Tiap 2 orang dalam 250 x 10 m \\
\hline
\end{tabular}

Sumber : Yulianda et al (2010)

Tabel 2 Prediksi waktu yang dibutuhkan untuk setiap kegiatan

\begin{tabular}{llll}
\hline No & Jenis kegiatan & Waktu yang dibutuhkan - Wp (jam) & Total waktu 1 hari - Wt (jam) \\
\hline 1 & Rekreasi pantai & 3 & 6 \\
2 & Wisata mangrove & 2 & 8 \\
3 & Wisata lamun & 2 & 4 \\
4 & Snorkeling & 3 & 6 \\
5 & Selam & 2 & 8 \\
\hline
\end{tabular}

Sumber : Yulianda et al (2010) 


\section{Hasil Dan Pembahasan}

Kegiatan ekowisata pesisir merupakan kegiatan rekreasi yang memanfaatkan potensi sumberdaya pesisir dan lingkungan perairan laut yang dilakukan disekitar pantai dan lepas pantai, antara lain seperti berenang, berjemur, menyelam, snorkeling dan tracking di hutan mangrove. Selain memanfaatkan potensi sumberdaya pesisir dan lautan (Dodds, 2007), kegiatan ekowisata pesisir di pulau- pulau kecil juga terkait dengan pemanfaatan potensi sumberdaya manusia yang dimiliki melalui nilai-nilai adat istiadat (budaya). Penentuan kesesuaian pesisir dilakukan dengan pemberian skoring terhadap parameter yang mendukung kegiatan wisata per kategori dan kesesuaian nilai budaya masyarakat setempat. Hasil analisis kesesuaian wisata dan daya dukung kawasan (DDP) di wilayah gugus Pulau Sapeken sebagai berikut :

\section{Kesesuaian Pemanfaatan untuk Kegiatan Wisata}

\section{a. Wisata Selam}

Komunitas terumbu karang dan obyek menarik lainnnya dapat dimanfaatkan sebagai daya tarik ekowisata selam. Keberadaan obyek wisata berupa terumbu karang di wilayah gugus Pulau Sapeken berada pada kedalaman 2 meter sampai 6 meter (FDC dan INNR, 2006). Terumbu karang masih dapat tumbuh baik sampai pada kedalaman maksimum 40 meter sampai 60 meter, tergantung pada tingkat kecerahan air. Selanjutnya, persyaratan lain yang harus dipenuhi meliputi persentase tutupan karang, salinitas, kedalaman karang dan kecepatan arus. Hasil analisa kesesuaian ekowisata untuk jenis wisata selam tiap pulau kecil di gugus Pulau Sapeken di tampilkan pada Tabel 9.

Tabel 3 Luas kesesuaian ekowisata jenis wisata selam di gugus Pulau Sapeken

\begin{tabular}{lllll}
\hline \multirow{2}{*}{ No } & \multicolumn{1}{c}{ Pulau } & Sesuai (S) & $\begin{array}{c}\text { Luas Kesesuaian (ha) } \\
\text { Sesuai Bersyarat (SB) }\end{array}$ & Tidak sesuai (TS) \\
\hline 1 & Pagerungan Besar & 118.53 & 260.27 & 304.81 \\
2 & Pagerungan Kecil & - & 88.08 & 106.62 \\
3 & Paliat & - & 330.64 & 17.99 \\
4 & Sapangkur Besar & - & 272.93 & 34.36 \\
5 & Sapeken & - & 18.37 & 237.22 \\
6 & Saor & - & 197.35 & 37.20 \\
7 & Sepanjang & 45.89 & 0.18 & 344.37 \\
Total & & 164.42 & 1167.82 & 1082.57 \\
\hline
\end{tabular}

Sumber : Hasil Analisa, 2012

Pengembangan kegiatan ekowisata untuk jenis wisata selam di gugus Pulau Sapeken, secara umum menunjukkan tingkat kesesuaian sesuai bersyarat seluas 1167.82 ha dan sesuai seluas 164.42 ha (Tabel 3) didasarkan atas delapan parameter kesesuaian. Hal ini menunjukkan bahwasanya di gugus Pulau Sapeken memiliki kondisi biofisik perairan yang mendukung bagi kegiatan ekowisata untuk jenis wisata selam. Pada pulau kecil yang memiliki tingkat kesesuaian sesuai bersyarat (SB), pemenuhan parameter yang membedakan adalah tutupan komunitas karang dan jenis life form.

\section{b. Wisata Snorkeling}

Ekowisata untuk jenis wisata snorkeling memilki persamaan dengan jenis wisata selam, terkait obyek wisata, yaitu ekosistem terumbu karang. Parameter yang membedakan jenis wisata snorkeling dan selam dalam analisa kesesuaian adalah kedalaman terumbu karang ditemukan. Pada jenis wisata snorkeling mensyaratkan terumbu karang ditemukan pada kedalaman $1-3$ meter (Hutabarat et al, 2009). Hal inilah yang menjadikan jenis wisata snorkeling dikenal juga sebagai skin diving. Selain kedalaman 
terumbu karang, parameter lainnya yang diperlukan dalam analisa kesesuaian ekowisata untuk jenis wisata snorkeling meliputi prosentase life form, kecerahan perairan, jenis ikan karang, kecepatan arus dan lebar hamparan datar karang. Untuk luas kesesuaian ekowisata jenis wisata selam di gugus Pulau Sapeken ditampilkan pada Tabel 4.

Tabel 4 Luas kesesuaian ekowisata untuk jenis wisata snorkeling di gugus Pulau Sapeken

\begin{tabular}{lllll}
\hline \multirow{2}{*}{ No } & \multicolumn{1}{c}{ Pulau } & \multicolumn{1}{c}{ Sesuai (S) } & \multicolumn{1}{c}{$\begin{array}{l}\text { Luas Kesesuaian (ha) } \\
\text { Sesuai Bersyarat (SB) }\end{array}$} & Tidak sesuai (TS) \\
\hline 1 & Pagerungan Besar & 361.56 & 2.48 & 319.56 \\
2 & Pagerungan Kecil & - & 84.85 & 109.86 \\
3 & Paliat & - & - & 348.63 \\
4 & Sapangkur Besar & - & 269.39 & 37.90 \\
5 & Sapeken & - & - & 255.59 \\
6 & Saor & - & 74.71 & 159.85 \\
7 & Sepanjang & - & 103.58 & 286.86 \\
Total & & 361.56 & 535.01 & 1518.25 \\
\hline
\end{tabular}

Sumber : Hasil Analisa, 2012

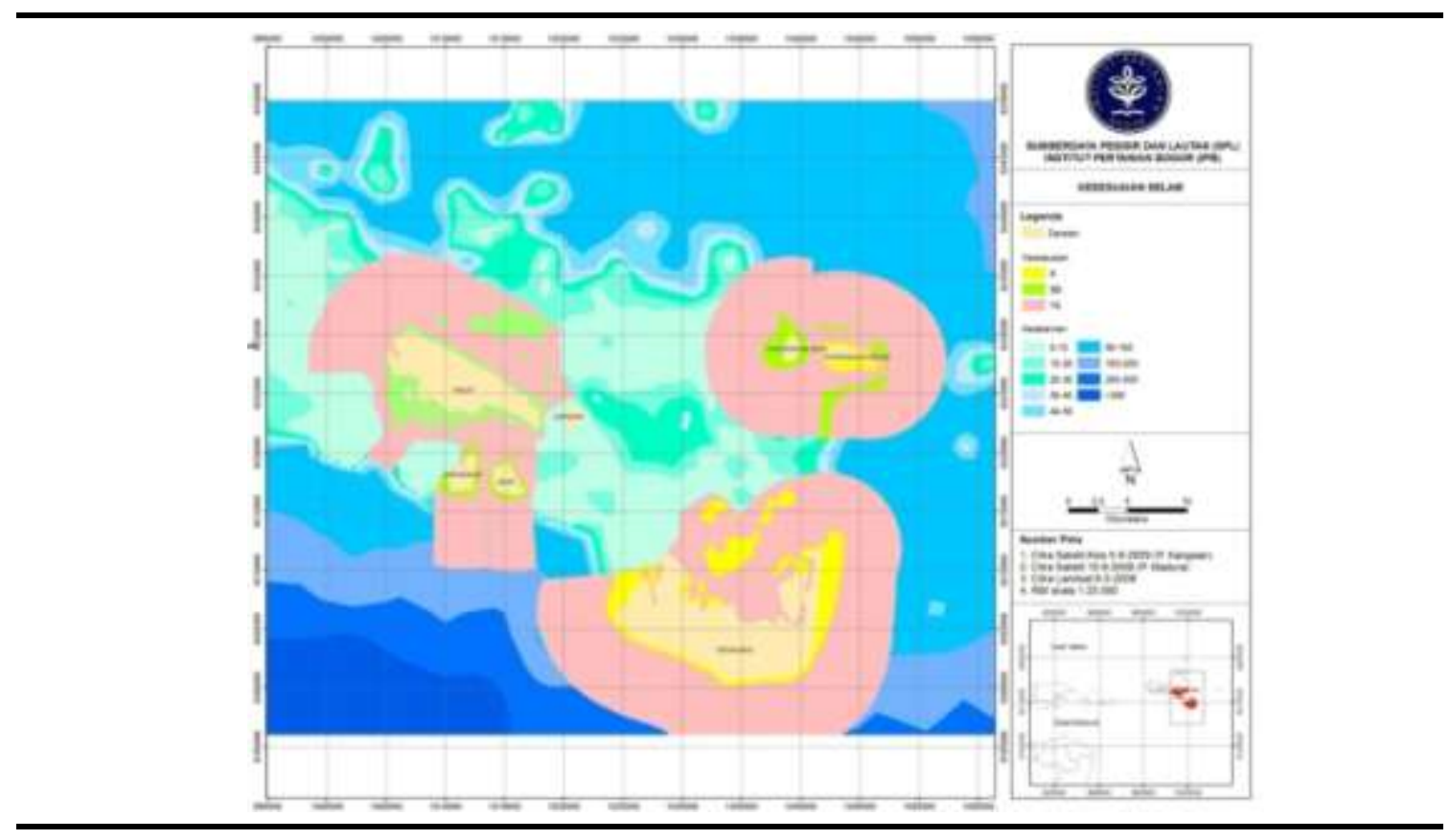

Gambar 2 Peta kesesuaian ekowisata jenis wisata selam di gugus Pulau Sapeken

Hasil kesesuaian kegiatan ekowisata untuk jenis wisata snorkeling di gugus Pulau Sapeken (Tabel 6) menunjukkan kesesuaian untuk kelas tidak sesuai (TS) seluas 1518.25 ha, kelas sesuai bersyarat (SB) seluas 535.01 ha, dengan faktor pembatas berupa tutupan komunitas karang dan jenis life form, serta kelas sesuai (S) seluas 361.56 ha. Umumnya tutupan komunitas karang dan jenis life form yang ada di gugus Pulau Sapeken berada pada kisaran 25\% - 65\% dan bentuk pertumbuhan mayoritas adalah Acropora tabulate, Acropora branching, Coral branching dan Coral massive(KEI, 2008). Kondisi tutupan dan jenis life form tersebut hanya memiliki skor 2 dalam analisa kesesuaian ekowisata untuk jenis wisata snorkeling. Untuk Pulau Sapeken dan Pulau Paliat dengan kelas kesesuaian tidak sesuai memiliki faktor pembatas selain berupa tutupan komunitas karang dan jenis life form, juga memiliki faktor pembatas berupa kedalaman karang dan lebar hamparan datar karang. 


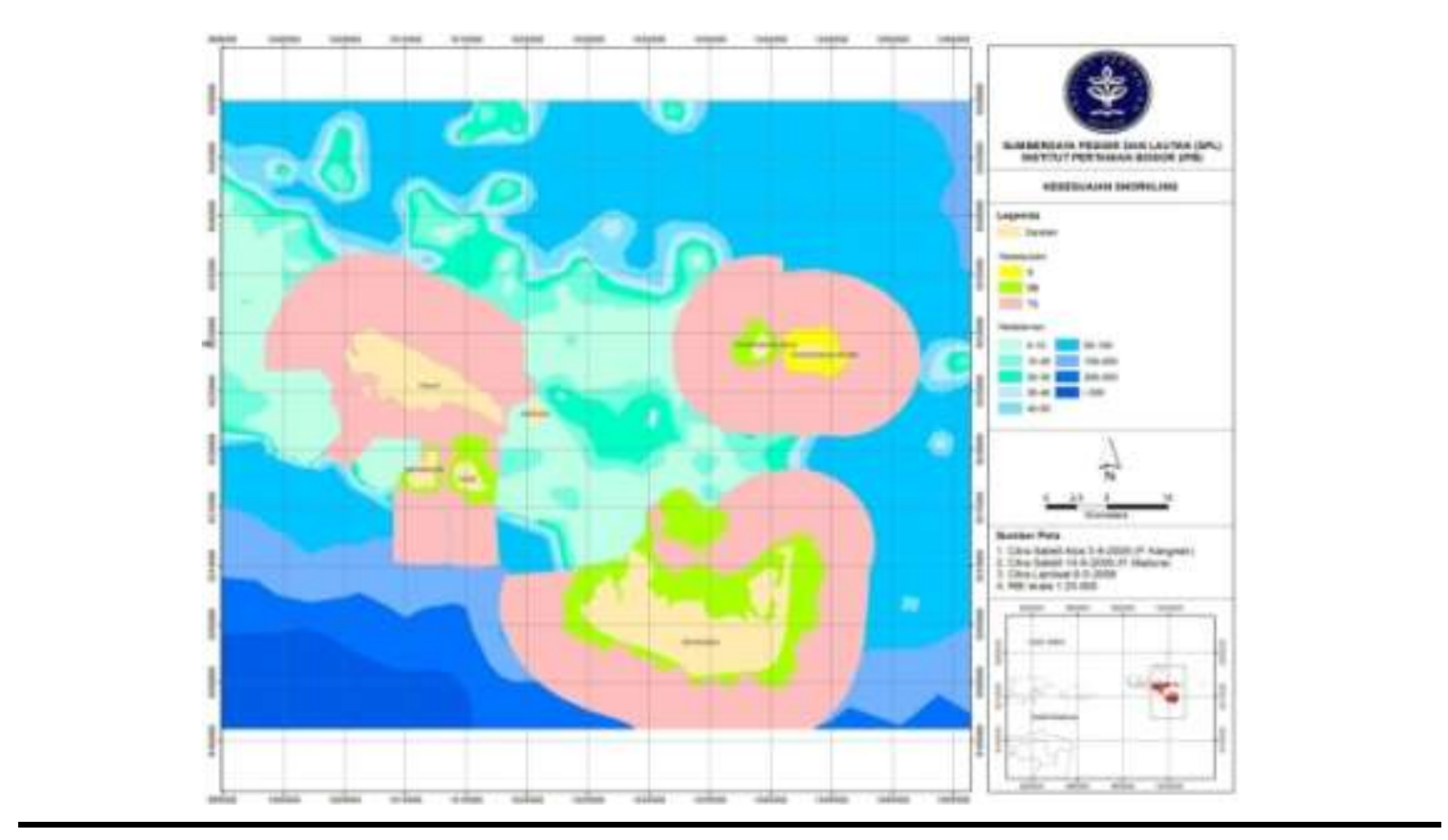

Gambar 3 Peta kesesuaian ekowisata jenis wisata snorkeling di gugus Pulau Sapeken

\section{c. Wisata Pancing}

Rekreasi memancingadalah salah satukegiatan rekreasiyang paling umumdi wilayah pesisirdi seluruh dunia, melibatkansejumlah besar orangdan berpengaruh terhadap usaha penangkapan(Westera etal., 2003). Pentingnyarekreasi perikananbagi perekonomianlokal dan nasional, dan sebagaigeneratorkesejahteraan sosialbesardi seluruhnegara maju(Cowxetal., 2010). Di beberapa daerahpesisir, pentingnyaekonomirekreasi memancingsamaatau bahkanmelampaui daripenangkapan ikan komersial(CookedanCowx, 2006).

Gugus Pulau Sapeken merupakan kawasan yang dikelilingi oleh perairan laut. Sumberdaya perikanan tangkap merupakan potensi terbesar dan paling realistis untuk dimanfaatkan secara berkelanjutan. Ekowisata pancing merupakan salah satu bentuk kegiatan wisata yang mengandalkan sumberdaya perikanan sebagai daya tarik wisata. Tidak kurang 30 famili ikan yang teridentifikasi di gugus Pulau Sapeken. Kondisi ini merupakan daya tarik bagi pengembangan ekowisata untuk jenis wisata pancing. Untuk luas kesesuaian ekowisata untuk jenis wisata pancing tiap kelas kesesuaian di gugus Pulau Sapeken, ditampilkan pada Tabel 5.

Tabel 5 Luas kesesuaian ekowisata jenis wisata pancing di gugus Pulau Sapeken

\begin{tabular}{|c|c|c|c|c|}
\hline \multirow{2}{*}{ No } & \multirow{2}{*}{ Pulau } & \multicolumn{3}{|c|}{ Luas Kesesuaian (ha) } \\
\hline & & Sesuai (S) & Sesuai Bersyarat (SB) & Tidak sesuai (TS) \\
\hline 1 & Pagerungan Besar & & 185.45 & 113.77 \\
\hline 2 & Pagerungan Kecil & & 668.92 & 485.40 \\
\hline 3 & Paliat & & 166.96 & 46.00 \\
\hline 4 & Sapangkur Besar & & 91.26 & 271.33 \\
\hline 5 & Sapeken & & 25.51 & 2.31 \\
\hline 6 & Saor & & 174.06 & 21.77 \\
\hline 7 & Sepanjang & & 181.22 & 243.03 \\
\hline Total & & & 1493.38 & 1183.61 \\
\hline
\end{tabular}

Sumber : Hasil analisa, 2012 
Parameter utama untuk analisa kesesuaian untuk jenis wisata pancing adalah kelompok jenis ikan, tinggi gelombang dan kecepatan arus. Hasil analisa kesesuaian ekowisata untuk jenis wisata pancing secara umum menunjukkan, wilayah di gugus Pulau Sapeken memiliki kelas kesesuaian sesuai bersyarat(SB) seluas 1493.38 ha dan tidak sesuai (TS) seluas 1183.61 ha dengan faktor pembatas berupa tinggi gelombang dan kecepatan arus

Tinggi gelombang dan kecepatan arus merupakan parameter dalam menentukan kesesuaian kawasan bagi peruntukan jenis wisata pancing. Kondisi oseanografi (gelombang dan arus) pada suatu perairan memegang peranan penting dalam menentukan alokasi pemanfaatan sumberdaya, terkait aspek keamanan dan keselamatan bagi pengguna (nelayan atau wisatawan) dalam melakukan aktivitas di laut (Sugiharti, 2000). Berkaitan dengan hal tersebut tinggi gelombang dan arus menentukan memberikan keamanan, keselamatan sekaligus kenyamanan bagi wisatawan. Tinggi gelombang optimal bagi ekowisata jenis wisata pancing yaitu kurang dari 1 meter, sedangkan kecepatan arus kurang dari $20 \mathrm{~cm} /$ detik. Adapun tinggi gelombang pada wilayah gugus Pulau Sapeken pada musim barat bisa mencapai 3 meter dan kecepatan arus $30-40 \mathrm{~cm} /$ detik. Terkait dengan hal tersebut, ekowisata jenis wisata pancing hanya dapat dilakukan pada saat musim tertentu saja, dimana tinggi gelombang berkisar antara $1-1.5$ meter dan kecepatan arus dibawah $30 \mathrm{~cm} /$ detik.

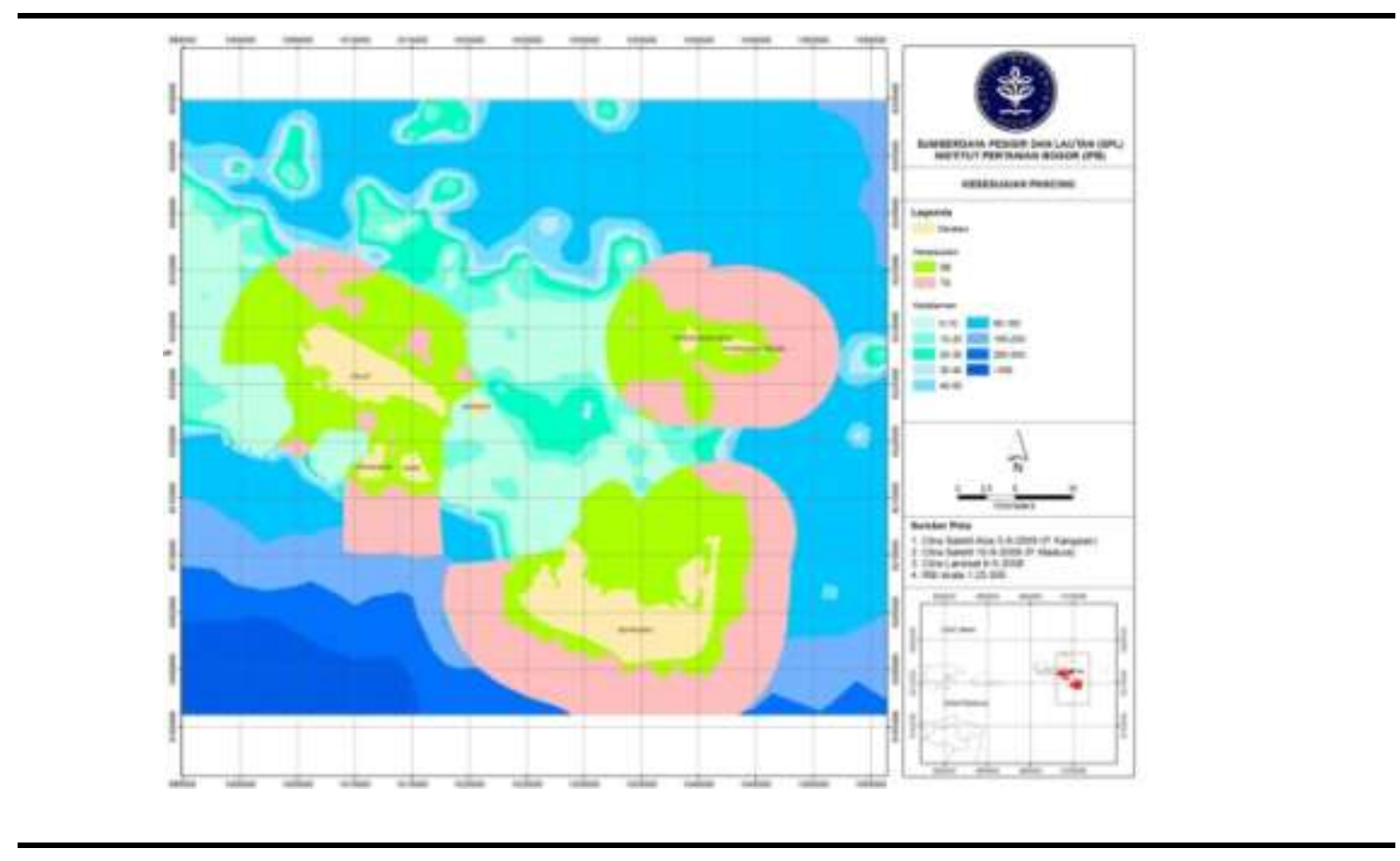

Gambar 4Peta kesesuaian ekowisata jenis wisatapancing di gugus Pulau Sapeken

\section{d. Wisata Mangrove}

Mangrove adalah salah satu ekosistem paling produktif di bumi dan menempati zona intertidal dan supratidal di sepanjang pantai tropis dan subtropis (ITTO, 2002). Ekosistem mangrove secara luas memiliki fungsi habitat untuk ikan dan krustasea, memiliki nilai komersial, perangkap sedimen yang efektif, daur ulang nutrisi dan perlindungan garis pantai dari erosi. Ekosistem mangrove juga menawarkan sejumlah besar produk berupa kayu bakar, kayu, madu, lilin dan tanin (FAO, 2007). Terlepas dari nilai ekologi, mangrove 
memiliki estetika, nilai sejarah, dan budaya (Duke et al, 2007). Salah satu bentuk pemanfaatan nilai - nilai yang ada pada ekosistem mangrove adalah melalui kegiatan ekowisata. Ekowisata merupakan sarana dalam mewujudkan sustainable livelihoods, pelestarian budaya dan konservasi keanekaragaman hayati (Hunter, 2002).

Keberadaan ekosistem mangrove pada wilayah gugus Pulau Sapeken hanya ditemukan di Pulau Pagerungan Besar, Sapangkur Besar, Paliat dan Sepanjang, dengan luasan terbesar terdapat di Pulau Sepanjang \pm 3657.8 ha (Perhutani, 2010). Jenis mangrove yang umumnya ditemukan adalah Rhizophora apiculata, Rhizophora mucronata, Avicennia offionalis, Bruguiera cylindrica dan Ceriops decandra (Suhardjono dan Rugayah, 2007). Lebih lanjut disebutkan jenis mangrove terbesar terdapat di Pulau Sepanjang, yaitu 36 jenis.Terdapat enam parameter dalam kesesuaian kegiatan ekowisata untuk jenis wisata mangrove, yaitu ketebalan mangrove, kerapatan mangrove, jenis mangrove, jenis biota, tinggi pasut dan jarak dari kawasan lainnya. Daya tarik utama dari jenis wisata mangrove ini adalah keberadaan mangrove beserta komunitas biota yang ada didalamnya. Luas kesesuaian ekowisata untuk jenis wisata mangrove tiap kelas kesesuaian di gugus Pulau Sapeken, ditampilkan pada Tabel 6.

Tabel 6 Luas kesesuaian ekowisata jenis wisata mangrove di gugus Pulau Sapeken

\begin{tabular}{|c|c|c|c|c|}
\hline \multirow{2}{*}{ No } & \multirow{2}{*}{ Pulau } & \multicolumn{3}{|c|}{ Luas Kesesuaian (ha) } \\
\hline & & Sesuai (S) & Sesuai Bersyarat (SB) & Tidak sesuai (TS) \\
\hline 1 & Pagerungan Besar & ב & - & 3.89 \\
\hline 2 & Pagerungan Kecil & - & - & - \\
\hline 3 & Paliat & 607.34 & 42.62 & 63.93 \\
\hline 4 & Sapangkur Besar & - & 14.88 & - \\
\hline 5 & Sapeken & - & - & - \\
\hline 6 & Saor & - & - & - \\
\hline 7 & Sepanjang & 3319.75 & 40.19 & 14.31 \\
\hline Total & & 3927.09 & 97.69 & 82.13 \\
\hline
\end{tabular}

Sumber : Hasil analisa, 2012

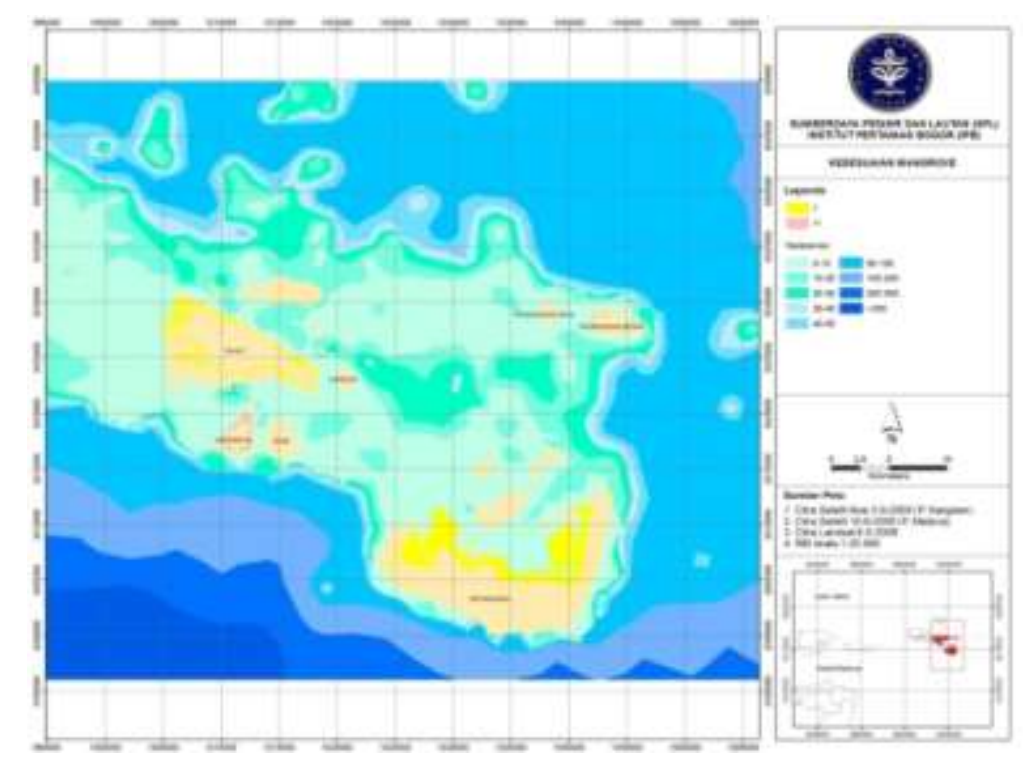

Gambar 5 Peta kesesuaian ekowisata jenis wisatamangrove di gugus Pulau Sapeken 
Hasil penilaian kesesuaian ekowisata jenis wisata mangrove menunjukkan untuk ekosistem mangrove di gugus Pulau Sapeken memiliki kelas kesesuaian yang berbeda yaitu kelas kesesuaian sesuai (S) 3927.09 ha,sesuai bersyarat (SB) 97.67 ha dan tidak sesuai (TS) 82.13 ha. Faktor pembatas yang mempengaruhi meliputi jenis, ketebalan dan kerapatan mangrove. Mangrove pada Pulau Pagerungan Besar dan Sapangkur Besar tidak memiliki ketebalan dan kerapatan mangrove yang berpotensi untuk dikembangkan ekowisata jenis wisata mangrove. Ketebalan mangrove pada Pulau Pagerungan Besar hanya 75 meter dan jenis mangrove yang dijumpai hanya Rhizophora apiculata, Rhizophora mucronata dengan kerapatan 7 individu $/ 100 \mathrm{~m}^{2}$.

\section{e. Wisata Pantai}

Wilayah kepulauan memiliki sejumlah daya tarik dari keberadaan sejumlah ekosistem untuk dijadikan destinasi wisata. Salah satu daya tarik tersebut adalah ekosistem pantai. Pantai di gugus Pulau Sapeken memiliki natural landscape yang dapat dijadikan sebagai daya tarik wisata, ditunjukkan dengan tipe pantai dan material dasar perairan. Lebih lanjut dijelaskan oleh Agarwal (2002) bahwasanya keberadaan ekosistem pantai bagi sebuah pulau kecil, berpotensi untuk dikembangkan kegiatan wisata sekaligus akan meningkatkan perekonomian masyarakat yang ada. Kesesuaian pemanfataan untuk kegiatan ekowisata jenis wisata pantai didasarkan atas pemenuhan sejumlah parameter, meliputi tipe pantai, lebar pantai, kedalaman perairan, material dasar perairan, kecepatan arus, kemiringan pantai, kecerahan perairan, penutupan lahan pantai, biota berbahaya dan ketersediaan air tawar. Luas kesesuaian ekowisata untuk jenis wisata pantai tiap kelas kesesuaian di gugus Pulau Sapeken, ditampilkan pada Tabel 7.

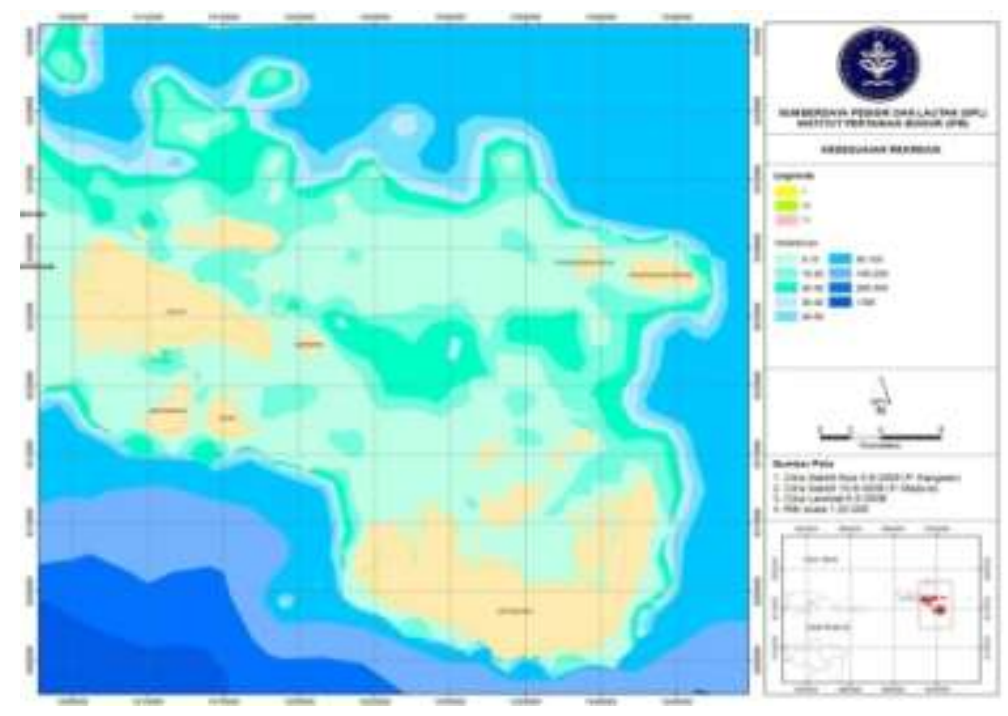

Gambar 6 Peta kesesuaian ekowisata jenis wisata pantai di gugus Pulau Sapeken

Kesesuaian ekowisata untuk jenis wisata pantai di gugus Pulau Sapeken pada umumnya memiliki kelas kesesuaian bersyarat (SB) seluas 39,77 ha dengan faktor pembatas berupa tipe pantai dan kedalaman perairan, kelas kesesuaian sesuai seluas 3.89 ha, kelas kesesuaian tidak sesuai (TS) seluas 53.95 ha dengan faktor pembatas berupa tipe pantai, kedalaman perairan dan penutupan lahan pantai. 
Tabel 7 Luas kesesuaian ekowisata jenis wisata pantai di gugus Pulau Sapeken

\begin{tabular}{|c|c|c|c|c|}
\hline \multirow{2}{*}{ No } & \multirow{2}{*}{ Pulau } & \multicolumn{3}{|c|}{ Luas Kesesuaian (ha) } \\
\hline & & Sesuai (S) & Sesuai Bersyarat (SB) & Tidak sesuai (TS) \\
\hline 1 & Pagerungan Besar & 3.89 & 0.56 & 19.24 \\
\hline 2 & Pagerungan Kecil & - & 5.93 & 11.81 \\
\hline 3 & Paliat & - & 7.41 & 3.34 \\
\hline 4 & Sapangkur Besar & - & 4.23 & 3.80 \\
\hline 5 & Sapeken & - & - & 8.21 \\
\hline 6 & Saor & - & 1.33 & 1.53 \\
\hline 7 & Sepanjang & - & 20.31 & 6.05 \\
\hline Total & & 3.89 & 39.77 & 53.98 \\
\hline
\end{tabular}

Sumber : Hasil analisa, 2012

\section{Daya Dukung Kawasan untuk Kegiatan Wisata}

Daya dukung kegiatan wisata di gugus Pulau Sapeken dilakukan dengan pendekatan potensi ekologis pengunjung per satuan unit area, luas lahan yang dapat dimanfaatkan (kelas kesesuaian sesuai (S) dan sesuai bersyarat (SB), unit area, waktu yang disediakan oleh kawasan dalam 1 hari dan waktu yang dihabiskan oleh pengunjung untuk melakukan aktifitas wisata. Berikut hasil analisa daya dukung kegiatan wisata di gugus Pulau Sapeken.

\section{a. Wisata Selam}

Ekosistem terumbu karang merupakan salah satu archipelago destinations yang dijadikan sebagai daya tarik. Kondisi ekosistem terumbu karang dipresentasikan melalui tutupan komunitas karang dan jenis life form, akan menghasilkan pemandangan bawah laut yang menarik (scenery) berupa bentuk terumbu karang dan biota yang ada. Wisata selam merupakan wisata berbasis obyek alam (tourism based nature), yang sangat tergantung pada kondisi lingkungan (Uyarra et al, 2009). Ancaman terbesar dari kelestarian ekosistem terumbu karang di gugus Pulau Sapeken adalah kegiatan penangkapan ikan hias dengan menggunakan sianida, pemboman dan penggunaan karang sebagai bahan konstruksi bangunan. Terkait dengan hal tersebut diperlukan upaya pengelolaan untuk mempertahankan kondisi terumbu karang agar tetap mampu dijadikan daya tarik sekaligus meningkatkan kelas kesesuaian, melalui kegiatan konservasi dan rehabilitasi ekosistem terumbu karang.

Tabel 8. Daya Dukung Kawasan (DDK) dan Daya Dukung Pemanfaatan (DDP) wisata selam di gugus Pulau Sapeken

\begin{tabular}{|c|c|c|c|c|c|c|}
\hline No & Pulau & $\begin{array}{l}\text { Luas / } \\
\text { Panjang Area (m2) }\end{array}$ & $\begin{array}{l}\text { Daya } \\
\text { Kawasan }\end{array}$ & Dukung & $\begin{array}{l}\text { Daya } \\
\text { Pemanfaatan }\end{array}$ & Dukung \\
\hline 1 & Pagerungan Besar & $3.79 \mathrm{E}+06$ & $1.21 \mathrm{E}+04$ & & $1.21 \mathrm{E}+03$ & \\
\hline 2 & Pagerungan Kecil & $8.81 \mathrm{E}+05$ & $2.82 E+03$ & & $2.82 \mathrm{E}+02$ & \\
\hline 3 & Paliat & $3.31 \mathrm{E}+06$ & $1.06 \mathrm{E}+04$ & & $1.06 \mathrm{E}+03$ & \\
\hline 4 & Sapangkur Besar & $2.73 E+06$ & $8.73 E+03$ & & $8.73 E+02$ & \\
\hline 5 & Sapeken & $1.84 \mathrm{E}+05$ & $5.88 E+02$ & & $5.88 \mathrm{E}+01$ & \\
\hline 6 & Saor & $1.97 \mathrm{E}+06$ & $6.32 E+03$ & & $6.32 \mathrm{E}+02$ & \\
\hline 7 & Sepanjang & $4.61 \mathrm{E}+05$ & $1.47 \mathrm{E}+03$ & & $1.47 \mathrm{E}+02$ & \\
\hline Total & & & & & $4.26 \mathrm{E}+03$ & \\
\hline
\end{tabular}

Sumber : Hasil analisa, 2012 
Upaya selanjutnya dalam mempertahankan kondisi ekosistem terumbu karang melalui pembatasan jumlah wisatawan kegiatan ekowisata untuk jenis wisata selam. Keberadaan wisatawan yang berinteraksi langsung dengan komunitas terumbu karang menyebabkan sejumlah kerusakan terhadap terumbu karang seperti kemungkinan terinjak, sedimen tersuspensi dan fin contact (Chabanet et al, 2005). Lebih lanjut Rodgers dan Cox (2003) menjelaskan bahwasanya tingkat kerusakan fisik terumbu karang memiliki korelasi dengan jumlah pengunjung. Terkait dengan hal tersebut, dalam pengembangan kegiatan ekowisata jenis wisata selam di gugus Pulau Sapeken, perlu dinilai daya dukung pemanfaatan (DDP) untuk jenis wisata selam. Adapun DDP wisata selam untuk kelas kesesuaian sesuai (S) dan sesuai bersyarat (SB), sebagai berikut :

Nilai DDP untuk ekowisata jenis wisata selam di gugus Pulau Sapeken tersebut menunjukkan batas atau limit jumlah wisatawan per harinya. Batasan jumlah wisatawan ini memegang peranan penting dalam mengatur dan mengelola kerusakan fisik yang mungkin ditimbulkan (Cesar, 2003). Ditambahkan, Leujak dan Ormond (2007)menjelaskan bahwasanya batasan jumlah wisatawan akan menghindari penurunan daya tarik lingkungan sekaligus sebagai sarana dalam pengelolaan wisata secara berkelanjutan. Batasan jumlah wisatawan untuk kegiatan ekowisata jenis wisata selam di gugus Pulau Sapeken sebesar 4260 wisatawan. Jumlah wisatawan tersebut mengindikasikan daya dukung pemanfaatan tiap hari yang diperbolehkan sekaligus tetap menjaga kondisi ekosistem terumbu karang.

\section{b. Wisata Snorkeling}

Kemudahan dalam melakukan jenis wisata snorkeling menjadikan ekosistem terumbu karang memiliki kemungkinan untuk terganggu lebih besar, akibat terinjak, suspensi sedimen dan patahnya coral branching oleh wisatawan yang belum mahir menyelam. Salah satu upaya yang dapat dilakukan untuk mengatasi hal tersebut Roman et al (2007) menyarankan pembuatan snorkelling trail dengan melibatkan partisipasi masyarakat. Keberadaan snorkelling trail akan membuat wisatawan berada pada jalur dengan jarak aman tertentu yang telah dibuat sehingga mengurangi kemungkinan terumbu karang diinjak atau patah. Kedalaman snorkelling trail, diusahakan pada kedalaman 2 meter untuk meminimalkan kontak fins dengan dasar perairan.

Tabel 9. Daya Dukung Kawasan (DDK) dan Daya Dukung Pemanfaatan (DDP) wisata snorkeling di gugus Pulau Sapeken

\begin{tabular}{|c|c|c|c|c|}
\hline No & Pulau & $\begin{array}{l}\text { Luas / } \\
\text { Panjang Area (m2) }\end{array}$ & $\begin{array}{l}\text { Daya Dukung } \\
\text { Kawasan }\end{array}$ & Daya Dukung Pemanfaatan \\
\hline 1 & Pagerungan Besar & $3.64 \mathrm{E}+06$ & $1.46 \mathrm{E}+04$ & $1.46 \mathrm{E}+03$ \\
\hline 2 & Pagerungan Kecil & $8.48 \mathrm{E}+05$ & $3.39 \mathrm{E}+03$ & $3.39 \mathrm{E}+02$ \\
\hline 3 & Paliat & - & - & - \\
\hline 4 & Sapangkur Besar & $2.69 \mathrm{E}+06$ & $1.08 \mathrm{E}+04$ & $1.08 \mathrm{E}+03$ \\
\hline 5 & Sapeken & - & - & - \\
\hline 6 & Saor & $7.47 \mathrm{E}+05$ & $2.99 \mathrm{E}+03$ & $2.99 \mathrm{E}+02$ \\
\hline 7 & Sepanjang & $1.04 \mathrm{E}+06$ & $4.14 \mathrm{E}+03$ & $4.14 \mathrm{E}+02$ \\
\hline \multicolumn{2}{|c|}{ Total } & & & $3.59 \mathrm{E}+03$ \\
\hline
\end{tabular}

Sumber : Hasil analisa, 2012

Upaya pengelolaan lainnya untuk mengatasi kerusakan terumbu karang akibat kegiatan ekowisata untuk jenis wisata snorkeling adalah dengan membuat terumbu karang buatan (artificial reef) sebagai alternatif spot. Pembuatan artificial reef dimaksudkan untuk mengalihkan tekanan dan dampak kegiatan wisata snorkeling. Langkah selanjutnya untuk mengurangi tekanan dan dampak kegiatan wisata snorkeling, adalah pembatasan jumlah wisatawan. Batasan jumlah wisatawan ini memegang peranan penting dalam mengatur dan 
mengelola kerusakan fisik yang mungkin ditimbulkan (Cesar, 2003). Terkait dengan hal tersebut, dalam pengembangan kegiatan ekowisata jenis wisata snorkeling di gugus Pulau Sapeken, perlu dinilai daya dukung pemanfaatan $(\mathrm{DDP}=3590)$ untuk jenis wisata snorkeling (Tabel 9). Nilai DDP untuk ekowisata jenis wisata snorkeling di gugus Pulau Sapeken tersebut menunjukkan batas atau limit jumlah wisatawan per harinya, sehingga ekosistem terumbu karang yang ada tetap dapat dimanfaatkan sebagai daya tarik wisata secara berkelanjutan.

\section{c. Wisata Pancing}

Kegiatan ekowisata jenis wisata pancing meskipun dianggap sebagai bentuk pemanfaatan sumberdaya perikanan yang lebih ramah lingkungan dibandingkan penangkapan ikan komersial, namun tetap berpotensi menyebabkan degradasi lingkungan. Intensitas tinggi dari kegiatan ekowisata jenis wisata pancing akan menyebabkan degradasi habitat yang berasal dari lalu lalang kapal di perairan dekat pantai (Bellan danBellanSantini, 2001). Terkait dengan hal tersebut, pembatasan jumlah wisatawan diperlukan sebagai bentuk pengelolaan agar sumberdaya perikanan sebagai daya tarik kegiatan ekowisata jenis wisata pancing tetap berkelanjutan sekaligus mempertahankan kondisi habitat yang ada. Batasan jumlah wisatawan merupakan daya dukung pemanfaatan (DDP), didasarkan atas luasan areal yang sesuai sekaligus waktu yang dibutuhkan dalam melakukan kegiatan wisata pancing. Besaran daya dukung pemanfaatan (DDP) kegiatan ekowisata untuk jenis wisata pancing di gugus Pulau Sapeken sebesar 14900 orang. Nilai tersebut menunjukkan jumlah wisatawan per hari yang dapat melakukan kegiatan ekowisata untuk jenis wisata pancing, tanpa menimbulkan penurunan kualitas lingkungan.

Tabel 10. Daya Dukung Kawasan (DDK) dan Daya Dukung Pemanfaatan (DDP) wisata pancing di gugus Pulau Sapeken

\begin{tabular}{|c|c|c|c|c|c|c|}
\hline No & Pulau & $\begin{array}{l}\text { Luas / } \\
\text { Panjang } \\
\text { (m2) }\end{array}$ & Area & $\begin{array}{l}\text { Daya Dukung } \\
\text { Kawasan }\end{array}$ & $\begin{array}{l}\text { Jumlah Unit } \\
\text { Sarana (JUSPI) }\end{array}$ & $\begin{array}{l}\text { Daya Dukung } \\
\text { Pemanfaatan }\end{array}$ \\
\hline 1 & Pagerungan Besar & $1.85 \mathrm{E}+06$ & & $5.56 \mathrm{E}+05$ & $6.18 \mathrm{E}+02$ & $1.85 \mathrm{E}+03$ \\
\hline 2 & Pagerungan Kecil & $6.69 \mathrm{E}+06$ & & $2.01 \mathrm{E}+06$ & $2.23 E+03$ & $6.69 \mathrm{E}+03$ \\
\hline 3 & Paliat & $1.67 \mathrm{E}+06$ & & $5.01 \mathrm{E}+05$ & $5.57 \mathrm{E}+02$ & $1.67 \mathrm{E}+03$ \\
\hline 4 & Sapangkur Besar & $9.13 E+05$ & & $2.74 \mathrm{E}+05$ & $3.04 \mathrm{E}+02$ & $9.13 \mathrm{E}+02$ \\
\hline 5 & Sapeken & $2.55 E+05$ & & $7.65 \mathrm{E}+04$ & $8.50 \mathrm{E}+01$ & $2.55 \mathrm{E}+02$ \\
\hline 6 & Saor & $1.74 \mathrm{E}+06$ & & $5.22 E+05$ & $5.80 \mathrm{E}+02$ & $1.74 \mathrm{E}+03$ \\
\hline 7 & Sepanjang & $1.81 \mathrm{E}+06$ & & $5.44 \mathrm{E}+05$ & $6.04 \mathrm{E}+02$ & $1.81 \mathrm{E}+03$ \\
\hline Total & & & & & & $1.49 \mathrm{E}+04$ \\
\hline
\end{tabular}

\section{d. Wisata mangrove}

Kondisi ekosistem mangrove yang direpresentasikan melalui jenis, ketebalan dan kerapatan mangrove merupakan daya tarik bagi ekowisata jenis wisata mangrove. Jenis wisata mangrove tergolong dalam wisata petualangan (outdooradventure tourism) dimana wisatawan melakukan aktivitas petualangan dengan menjelajah mangrove sekaligus menikmati pemandangan, hewan ataupun dengan menyusuri mangrve menggunakan perahu.Aktivitas wisatawan tentunya memiliki dampak terhadap ekosistem mangrove. Sashidaran et al (2002) menjelaskan bahwasanya pada prinsipnya secara keseluruhan kegiatan wisata akan meningkatkan konsumsi sumberdaya sekaligus menghasilkan limbah yang berpotensi merusak dan menghancurkan lingkungan. Lebih lanjut terkait dengan ekowisata jenis wisata mangrove, Priskin (2001) menjelaskan keberadaan wisatawan dan fasilitas wisata memicu kerusakan mangrove dan polusi. Terkait dengan tersebut, upaya 
pengelolaan yang dapat dilakukan adalah dengan mengatur jumlah wisatawan. Batasan jumlah wisatawan per hari yang didasarkan atas nilai daya dukung pemanfaatan (DDP) di gugus Pulau Sapeken sebesar 321000 orang (Tabel 11). Pengaturan jumlah wisatawan ini selain merupakan bentuk perlindungan, juga merupakan upaya untuk meningkatkan kepuasan dan kenyamanan bagi wisatawan dalam melakukan wisata mangrove. Upaya pengelolaan selanjutnya berupa pembuatan jalur penjelajahan (tracking) yang tidak menggangu aktivitas hewan yang ada didalamnya seperti tempat bersarang burung.

Tabel 11. Daya Dukung Kawasan (DDK) Dan Daya Dukung Pemanfaatan (DDP) Wisata Mangrove Di Gugus Pulau Sapeken

\begin{tabular}{llllll}
\hline No & Pulau & Luas / Panjang Area & $\begin{array}{l}\text { Daya } \\
\text { Kawasan }\end{array}$ & Dukung & $\begin{array}{l}\text { Daya } \\
\text { Pemanfaatan }\end{array}$ \\
\hline 1 & Pagerungan Besar & - & - & - \\
2 & Pagerungan Kecil & - & - & - \\
3 & Paliat & $6.50 \mathrm{E}+06$ & $5.20 \mathrm{E}+05$ & $5.20 \mathrm{E}+04$ \\
4 & Sapangkur Besar & - & - & - \\
5 & Sapeken & - & - & - \\
6 & Saor & - & - & - \\
7 & Sepanjang & $3.36 \mathrm{E}+07$ & $2.69 \mathrm{E}+06$ & $2.69 \mathrm{E}+05$ \\
\multicolumn{2}{l}{ Total } & & & $3.21 \mathrm{E}+05$ \\
\hline
\end{tabular}

Sumber : Hasil analisa, 2012

\section{e. Wisata Pantai}

Ekosistem pantai di gugus Pulau Sapeken umumnya merupakan pantai dengan kondisi biophisycal berupa pasir putih sebagai material dasar perairan, dengan kedalaman perairan berkisar antara 2 - 5 meter, hanya pada Pulau Sapeken material dasar perairannya berupa karang dengan kedalaman perairan 8 meter. Kelapa, semak dan lahan terbuka merupakan bentuk umum penutupan lahan pantai yang ada, hanya pada Pulau Pagerungan Besar ditemukan cemara udang (Casuarina aquisetifolia) yang dijadikan sebagai windbarrier. Kondisi biophisycal ekosistem pantai yang ada di gugus Pulau Sapeken tersebut tentunya merupakan daya tarik bagi ekowisata untuk jenis wisata pantai.

Kegiatan ekowisata untuk jenis wisata rekreasi di gugus Pulau Sapeken sebagai kawasan pulau-pulau kecil, lebih memiliki dampak yang lebih besar dibandingkan pada kawasan pantai di mainland. Perbedaan ini disebabkan selain dari karakteristik pulau kecil (ukuran kecil dan rentan terhadap gangguan), juga disebabkan keberadaan ekosistem lainnya yang saling berinteraksi misal ekosistem terumbu karang. Terumbu karang yang ada di gugus Pulau Sapeken umumnya ditemukan disepanjang pantai. Gangguan pada ekosistem pantai tentunya akan mempengaruhi ekosistem terumbu karang pula. Untuk itu, pengaturan terhadap bentuk aktivitas wisata yang ada diperlukan sebagai bentuk pengelolaan terpadu.

Selain aktivitas wisata yang perlu diperhatikan pada ekosistem pantai, pencemaran yang ditimbulkan dari aktivitas wisata, perlu juga mendapat perhatian. Pengawasan terhadap pencemaran yang diakibatkan aktivitas wisatawan dimaksudkan untuk tetap mempertahankan kondisi pantai dan ekosistem lainnya sehingga tetap dapat menyediakan jasa sekaligus kenyamanan dan kepuasan bagi wisatawan. Saarinen (2006) menyebutkan daya dukung dan keberlanjutan wisata merupakan point yang diperlukan untuk membatasi penggunaan sumberdaya untuk kegiatan wisata dengan mengurangi aktivitas wisata. Adapun batasan jumlah wisatawan kegiatan ekowisata untuk jenis wisata pantai yang dihitung dari nilai daya dukung pemanfaatan (DDP) di gugus Pulau Sapeken, sebesar 199 orang (Tabel 12). Terkait dengan hal tersebut pengaturan jumlah wisatawan diperlukan untuk membatasi aktivitas wisata sehingga tidak melampaui daya dukung ekosistem pantai. sekaligus mengurangi pencemaran yang ditimbulkan. 
Tabel 12. Daya Dukung Kawasan (DDK) Dan Daya Dukung Pemanfaatan (DDP) Wisata Mangrove Di Gugus Pulau Sapeken

\begin{tabular}{lllll}
\hline No & Pulau & Luas / Panjang Area & $\begin{array}{l}\text { Daya Dukung } \\
\text { Kawasan }\end{array}$ & $\begin{array}{l}\text { Daya Dukung } \\
\text { Pemanfaatan }\end{array}$ \\
\hline 1 & Pagerungan Besar & $4.46 \mathrm{E}+03$ & $1.78 \mathrm{E}+02$ & $1.78 \mathrm{E}+01$ \\
2 & Pagerungan Kecil & $5.93 \mathrm{E}+03$ & $2.37 \mathrm{E}+02$ & $2.37 \mathrm{E}+01$ \\
3 & Paliat & $7.41 \mathrm{E}+03$ & $2.96 \mathrm{E}+02$ & $2.96 \mathrm{E}+01$ \\
4 & Sapangkur Besar & $4.23 \mathrm{E}+03$ & $1.69 \mathrm{E}+02$ & $1.69 \mathrm{E}+01$ \\
5 & Sapeken & - & - & - \\
6 & Saor & $1.33 \mathrm{E}+03$ & $5.30 \mathrm{E}+01$ & $5.30 \mathrm{E}+00$ \\
7 & Sepanjang & $2.64 \mathrm{E}+04$ & $1.05 \mathrm{E}+03$ & $1.05 \mathrm{E}+02$ \\
Total & & & $1.99 \mathrm{E}+02$ \\
\hline
\end{tabular}

Sumber : Hasil analisa, 2012

\section{Kesimpulan}

Berdasarkan hasil penelitian dan pembahasan yang telah diuraikan, kesimpulan yang dapat dirumuskan adalah sebagai berikut :

1. Gugus Pulau Sapeken memiliki kesesuaian untuk pemanfaatan sejumlah kegiatan wisata. Hal ini ditunjukkan dengan kondisi ekosistem dan biofisik mendukung bagi pengembangan kegiatan wisata. Luasan pemanfaatan gugus Pulau Sapeken untuk kegiatan wisata, sebagai berikut : a) wisata selam memiliki tingkat kesesuaian sesuai (S) seluas 164.42 hadansesuai bersyarat (SB) seluas 1167.82 ha; b) wisata snorkeling, memiliki tingkat kesesuaian sesuai(S) seluas 361.56 hadansesuai bersyarat(SB) seluas 535.01 ha; c) wisata pancing, memiliki tingkat kesesuaian sesuai bersyarat(SB) seluas 1493.38ha; d) wisata mangrove, memiliki tingkat kesesuaian sesuai(S) seluas 3927.09 hadansesuai bersyarat(SB) seluas $97.67 \mathrm{ha}$; dan e) wisata pantai, memiliki tingkat kesesuaian sesuai bersyarat(SB) seluas 39.77 ha

2. Pemanfaatan ekosistem bagi kegiatan wisata di gugus Pulau Sapeken memiliki daya dukung. Daya dukung pemanfaatan ekosistem merupakan upaya untuk menjamin keberlangsungan sekaligus konservasi ekosistem sebagai implementasi pembangunan berkelanjutan. Daya dukung pemanfaatan (DDP) bagi kegiatan wisata di gugus Pulau Sapeken meliputi a) wisata selam 4260 orang/hari; b) wisata snorkeling 3590 orang/hari; c) wisata pancing 14900 orang/hari; d) wisata mangrove 321000 orang/hari; dan e) wisata pantai 199 orang/hari.

\section{Saran}

Kegiatan wisata pada gugus pulau kecil merupakan sebuah fenomena komplek dimana didalamnya tidak hanya dibutuhkan keberlanjutan ekonomi tetapi juga terkait dengan keberlanjutan social dan ekologi. Terkait dengan hal tersebut, penilaian terhadap daya dukung (carrying capacity) tidak hanya terbatas pada aspek biofisik saja tetapi juga mengikutsertakan aspek ekonomi dan sosial. dalam merealisasikan sustainable tourism.

\section{Daftar Pustaka}

[DKP] Departemen Kelautan dan Perikanan. 2000. Keputusan Menteri Kelautan dan Perikanan Nomor 41 Tahun 2000. Pedoman Umum Pengelolaan Pulau-Pulau Kecil yang Berkelanjutan dan Berbasis Masyarakat

[KEI Ltd.] Kangean Energy Indonesia. 2008. Kondisi Terumbu Karang Di Pulau Pagerungan Besar, Sepanang, Kangean Barat dan Karang Takat Kabupaten Sumenep, Provinsi Jawa Timur. Jakarta 
[KPH Perhutani] Kesatuan Pengelolaan Hutan Perusahaan Hutan Negara Indonesia. 2010. Laporan Tahunan Lokasi Kawasan Hutan Berdasarkan Fungsi dan Luasan Kabupaten Sumenep. Provinsi Jawa Timur

Agarwal, S. (2002). Restructuring seaside tourism e the resort lifecycle. Annals of Tourism Research, 29, 25-55

Apostolopoulos, Y. and Gayle, D.J. (eds). 2002. Island Tourism and Sustainable Development: Caribbean, Pacific and Mediterranean Experiences. Westport, CT: Praeger.

Bardolet, E., Sheldon, PJ., 2008 Tourism in Archiplegos Hawai'i and the Balearics. Annals of Tourism Research, 35, 900-923

Bellan, G.L., Bellan-Santini, D.R., 2001. A review of littoral tourism, sport and leisure activities: consequences on marine flora and fauna. Aquatic Conservation: Marine and Freshwater Ecosystems 11, 325-333.

Bengen, D.G dan Retraubun, A.W.S. 2006. Menguak Realitas dan Urgensi Pengelolaan Berbasis Eko-Sosio Sistem Pulau-Pulau Kecil. Pusat Pembelajaran dan Pengembangan Pesisir dan Laut (P4L). ISBN 97998867-2-4

Cesar, H., 2003. Report on the Economic Valuation of the Egyptian Red Sea Coral Reef. Monitoring, Verification, and Evaluation (MVE). Unit of the Egyptian Environmental Policy Program

Chabanet, P., Adjeroud, M., Andréfouët, S., Bozec, Y.M., Jocelyne Ferraris, J., Garcìa- Charton, J.A., Schrimm, M., 2005. Human-induced physical disturbances and their indicators on coral reef habitats: a multi-scale approach. Aquatic Living Resource 18, 215-230.

Conlin, M. V. and Baum, T. (ed). 1995. Island Tourism: Management Principles and Practice. Chichester, UK: JohnWiley \& Sons

Cooke, S.J., Cowx, I.G., 2006. Contrasting recreational and commercial fishing: searching for common issues to promote unified conservation of fisheries resources and aquatic environments. Biol. Conserv. 128 (1), 93-108.

Cowx, I.G., Arlinghaus, R., Cooke, S.J., 2010. Harmonizing recreational fisheries and conservation objectives for aquatic biodiversity in inland waters. J. Fish Biol. 76, 2194-2215

Dodds R. 2007. Malta's tourism policy : standing still or advancing towards sustainability. Island Studies Journal, 2(1) : 47-66

Duke, N.C., Meynecke, J.O., Dittmann, S., Elisosn, A.M., Anger, K., Berger, U., Cannicci, S., Diele, K., Ewel, K.C., Field, C.D., Koedam, N., Lee, S.Y., Marchand, C., Nordhaus, I., Dahdouh-Guebas, F., 2007. A world without mangroves? Science 317 (5834), 41-42.

FAO, 2007. The World's Mangroves 1980-2005: A Thematic Study Prepared in the Framework of the Global Forest Resources Assessment 2005. FAO Forestry Paper 153, Food and Agriculture Organization of the United Nations, Rome, Italy

Hunter, C. 2002. Sustainable tourism and the touristic ecologicalfootprint. Environment, Development and Sustainability, 4(1), 7-20.

Hutabarat A, Yulianda F, Fahrudin A, Harteti S, Kusharjani. 2009. Pengelolaan pesisir dan laut secara terpadu, Bogor: Edisi I Pusdiklat Kehutanan, Deptan, SECEN-KOREA International Cooperation Agency

ITTO, 2002. ITTO Mangrove Workplan 2002-2006. International Tropical Timber Organization, Yokohama, Japan

Laporan Ilmiah Ekspedisi Zooxanthellae VIII. Kondisi dan Potensi Ekosistem Terumbu Karang Kecamatan Sapeken, Kabupaten Sumenep, Propinsi Jawa Timur. FDC - IPB dan INNR. Agustus 2006

Laporan Ilmiah Ekspedisi Zooxanthellae VIII. Kondisi dan Potensi Ekosistem Terumbu Karang Kecamatan Sapeken, Kabupaten Sumenep, Propinsi Jawa Timur. FDC - IPB dan INNR. Agustus 2006

Leujak, W., Ormond, R.F.G., 2007. Visitor perceptions and the shifting social carrying capacity of South Sinai's coral reefs. Environmental Management 39, 472-489.

Pavlikakis, G.E., Tsihrintzis, V.A., 2006. Perceptions and preferences of the local population in Eastern Macedonia and Thrace National Park in Greece. Landscape and Urban Planning 77 (1-2), 1-16.

Priskin, J., 2001. Assessment of natural resources for nature-based tourism: the case of the Central Coast Region of Western Australia. Tourism Management 22, 637-648

Rodgers, K.U.S., Cox, E.F., 2003. The effects of trampling on Hawaiian corals along a gradient of human use. Biological Conservation 112, 383-389

Roman, G., Dearden, P., Rollins, R., 2007. Application of zoning and "limits of acceptable change" to manage snorkeling tourism. Environmental Management 39, 819-830

Saarinen, J. 2006 Traditions of Sustainability in Tourism Studies. Annals of Tourism Research 33:1121-1140. 
Sasidharan, V., Sirakaya, E., Kerstetter, D., 2002. Developing countries and tourism ecolabels. Tourism Management 23, 161-174.

Sugiarti, 2000. Analisis Kebijakan Pemanfaatan Ruang Wilayah Pesisir di Kotamadya Dati II Pasuruan Jawa Timur. [tesis] Bogor; Program Pascasarjana, Institut Pertanian Bogor

Suhardjono, Rugayah, 2007. Keanekaragaman Tumbuhan Mangrove di Pulau Sepanjang, Jawa Timur, BIO DIVERSITAS ISSN: 1412-033XVolume 8, Nomor 2 April 2007 Halaman: 130-134

TIES. The International Ecotourism Society. 2006. www.ecotourism.org[3 Desember 2012]

Uyarra, M. C., Watkinson, A. R., \& Cote, I. M. (2009). Managing dive tourism for the sustainable use of coral reefs: validating diver perceptions of attractive site features. Environmental Management, 43, 1-16.

White, A.T., Rosales, R., 2001. Community-oriented tourism in the Philippines: role in economic development and conservation. In: Gossling, S. (Ed.), Tourism and Development in Tropical Islands: Political Ecology Perspectives. Edward Elgar Publishing Limited, Cheltenham, UK, pp. 237-262.

Yu, K.J., Li, D.H., Duan, T.W., 2001 Landscape security approach in planning of very sensitive site and GIS application). (Chinese Landscape Architecture) 1, 11-16

Yulianda, 2007 Ekowisata Bahari Sebagai Alternatif Pemanfaatan Sumberdaya Pesisir Berbasis Konservasi. Disampaikan pada Seminar Sains 21 Februari 2007 pada Departemen Manajemen Sumberdaya Perairan Fakultas Perikanan dan Ilmu Kelautan. Institut Pertanian Bogor 